\title{
Factors Influencing Users' Intentions to Use Mobile Government Applications in Saudi Arabia: TAM Applicability
}

\author{
Raed Alotaibi ${ }^{1,2}$, Luke Houghton ${ }^{1} \&$ Kuldeep Sandhu ${ }^{1}$ \\ ${ }^{1}$ Griffith business school, Griffith University \\ Brisbane, Australia \\ ${ }^{2}$ College of community, Shaqra University \\ Shaqra, Saudi Arabia
}

\begin{abstract}
M-government applications in Saudi Arabia are still at an early stage. In this study, a modified technology acceptance model (TAM) was used to identify and measure the factors that influence users' intentions to use m-government applications in Saudi Arabia. This study focuses on the relationships between behavioural intention to use (BIU) and six independent factors: three TAM constructs (perceived usefulness [PU], attitude towards use [ATU], and perceived ease of use [PEU]) and three external factors: perceived trustworthiness [TRU], perceived security [SEC], and awareness [AWAR]). Only PU, ATU and TRU had a significant positive influence on BIU for m-government applications. The results also showed that most participants had a positive attitude towards using mgovernment applications. Overall, the results demonstrate that the model is suitable in the Saudi m-government context.
\end{abstract}

Keywords-TAM; Saudi Arabia; e-government; m-government applications

\section{INTRODUCTION}

In 2005, the Saudi Government established Yesser to provide e-government services with the overall aim of making all government services ready for use by citizens anywhere and at any time by 2010 [1]. Some studies have asserted that egovernment initiatives in Saudi Arabia have been delayed, although there has been some progress in implementation [2, 3]. A recent study [4] stated that in developing countries like Saudi Arabia, the adoption of e-government services is poor.

M-government has been defined as the government providing services and information via mobile devices and wireless communication networks such as cellular phones, PDAs and their supporting systems to businesses, citizens, public employees and non-profit organizations [5]. Many studies claim that m-government is like e-government and it is considered a complementary subset [6]-[12]. It has been claimed that in Saudi Arabia, mobile phone use has seen massive growth among citizens [13]. In 2015 there were 53 million mobile subscriptions in Saudi Arabia, representing about $167.5 \%$ of the population almost two mobile subscriptions per person [14]. A recent study [15] claimed that most $(67 \%)$ of the Saudi population use a smart phone. Recent studies [16], [17] claimed that in Saudi Arabia, traditional methods transacting with government sectors are still very common and are preferred by citizens. The studies also asserted that Saudi citizens are yet to completely adopt m-government. Therefore, the Saudi Government can exploit this high use of mobile devices to provide government services via applications. Few m-government applications, however, have actually been adopted in Saudi Arabia. In fact, the use of m-government applications in Saudi Arabia is still in its infancy [18]-[21].

M-government provides government services to users via mobile technology to provide quick service, increase user mobility and enable easy access to services. It is considered a sophisticated way to provide government services to users through mobile devices [6]. It has been suggested that there are four types of m-government: 1) m-government-to-government (mG2G); 2) m-government-to-citizen (mG2C); 3) mgovernment-to-employee (mG2E); and 4) m-government-tobusiness (mG2B) [12]. This study focuses on mG2C to identify and measure the factors that influence users' intentions to use m-government applications, as it has been claimed that most interaction today is m-government-to-citizen [22]. Therefore, this study aims to measure some factors, found in literature review, that influence the intentions of Saudis to use mgovernment applications.

This study's contribution to knowledge is in understanding Saudi citizens' attitudes towards using m-government applications and the factors that influence users' intentions to use those applications. This information will help government decision makers involved in e-government and m-government initiatives. Acknowledging and addressing these factors will support future m-government applications and their implementation. Theoretically, this study examines and evaluates the applicability of a modified technology acceptance model (TAM) in the Saudi m-government context. More specifically, this study will evaluate the TAM's applicability by examining relationships between behavioural intention to use (BIU) and six independent factors: three TAM constructs (perceived usefulness [PU], attitude towards use [ATU] and perceived ease of use [PEU]) and three external factors (perceived trustworthiness [TRU], perceived security [SEC], and awareness [AWAR]). In this way we envisage a practical contribution by government decision makers and a theoretical contribution by TAM researchers. 
To conclude this study, there are three aims. They are as follows:

1) to measure the influence of external factors (TRU, SEC and AWAR) and TAM constructs (PU, ATU and PEU) on users' intentions to use m-government applications in the Saudi context;

2) to measure Saudi citizens' attitudes towards using mgovernment applications; and

3) to propose, examine, develop and validate a model of m-government that suits the Saudi cultural context.

\section{LITERATURE REVIEW}

\section{A. Relationship Between E-Government and M-Government}

M-government is considered another method to provide government services to citizens [23]. Many studies report that $\mathrm{m}$-government and e-government are essentially the same thing, but m-government can be considered a sophisticated type of e-government [24], [25]. Some studies consider egovernment to be a key component of m-government [26][29]. Another study claims that because m-government is an independent method of achieving government objectives through the provision of services and information, it is similar to e-government [30].

\section{B. Advantages, Goals and Objectives of M-Government}

M-government has the advantages of easy infrastructure setup, improved e-government efforts, ease of learning, inclusiveness, remote area access and low cost [12], [19], [30], [31]. It has been stated that the advantages of m-government include: the provision of location-based government services, on-time information delivery, mobility, ubiquity, time savings, ease of use and improved emergency management [32]. A recent study [25] confirmed all the m-government advantages noted in previous studies, but further highlighted two new advantages: international trade benefits and democratic reforms. Althunibat, Alrawashdeh, and Muhairat [6] claimed that the goal of m-government is to attract users to use government services, since m-government is easily accessible for services 24 hours a day, seven days a week. Along the same lines, it has been demonstrated that m-government improves connection methods between citizens and the government, encourages citizens to participate in local community matters, provides e-government services with certain additional features (e.g. timeliness, convenience, etc.) and implements and provides e-government services to citizens in distant locations for which the government has not previously provided services, such as rural areas [33].

\section{M-Government in Saudi Arabia}

M-government applications are already used to provide government services in most countries but most of these applications provide limited services, such as tracking systems for stolen vehicles, emergency assistance and weather updates [18]. In Saudi Arabia some services are already provided by mgovernment, such as Riyadh and Madinah Education, Appointments and Document Tracking, Health Mobile, tracking of Higher Education Information, and Employee Inquiry [34]. Although some applications in Saudi Arabia have been provided, m-government applications are still considered as being in the first stage of implementation [18]-[21]. Accordingly, researchers seek to identify and measure the factors that influence users' intentions to use m-government applications.

There is a lack of empirical studies that examine and validate the applicability of TAM in the Saudi m-government context. There is also a lack of empirical studies identifying and measuring factors that influence users' intentions to use mgovernment applications in Saudi Arabia.

\section{Theoretical Framework}

TAM is derived from the theory of reasoned action (TRA) that states that beliefs impact on intentions, and intentions impact on actions [35]. There are differences between TAM and TRA. TAM is used for the adoption of new technologies and focuses on users' attitudes, behaviours and perceptions in the adoption of this technology, while TRA is more general and used for various types of cases and adopted behaviours according to perceived positive outcomes [36].

TAM was first introduced in 1986 to measure new technology acceptance by users [37]. As shown in Fig. 1, TAM is expected to measure user acceptance of new technologies based on various factors, including behavioural intention to use, attitude towards use, perceived usefulness and perceived ease of use [38]. According to Davis [39], perceived usefulness can be defined as "the degree to which a person believes that using a particular system would enhance his or her job performance", and perceived ease of use can be defined as "the degree to which a person believes that using a particular system would be free of effort". Behavioural intention is defined as "the strength of one's intention to perform a specified behaviour" [40]. Attitudes can be defined as "an individual's positive or negative feelings (evaluative affect) about performing the target behaviour" [41].

TAM was selected as the research model in this study because it can determine the influence of external factors on attitude, intention to use, and belief [42]. As this study aims to study factors that influence behavioural intention to use (BIU) of m-government applications, TAM was chosen as the best model to predict user behaviour towards new technologies [42] because most other technology acceptance models only focus on technical factors [38]. According to Al-Hujran, Aldalahmeh, and Aloudat [40], TAM is used to predict and explain users' acceptance of new technologies, proposing that constructs like perceived usefulness and perceived ease of use are key factors in information system (IS) and information technology (IT) acceptance behaviours.

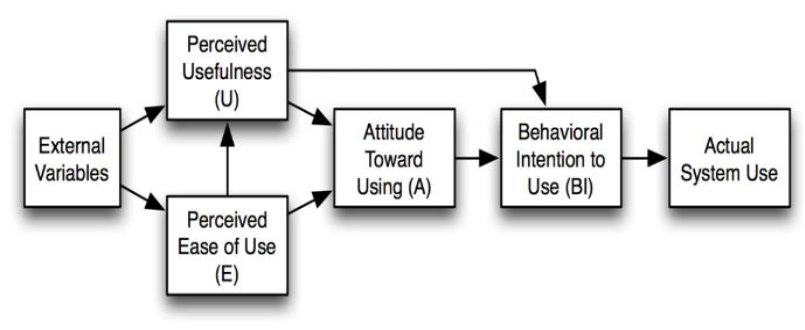

Fig. 1. The Technology Acceptance Model (TAM) [39]. 
TAM is one of the most effective research models to determine factor acceptance of information systems/technology [43]. TAM is also commonly used to measure user behaviour and to identify the factors influencing users' acceptance of new technologies [38], [44]-[46].

\section{E. Research Model and Hypotheses}

The original basic TAM was modified to achieve the study's objectives by including three external factors. Therefore, this study focuses on the relationships between behavioural intention to use (BIU) and six independent factors, either TAM constructs (perceived usefulness [PU], attitude towards use [ATU], and perceived ease of use [PEU]) or external factors (perceived trustworthiness [TRU], perceived security [SEC], and awareness [AWAR]) to identify and measure the factors that influence users' intentions to use $\mathrm{m}$ government applications in the Saudi context. The research model for this study is presented in Fig. 2.

1) Hypotheses for relationships between TAM constructs and BIU: Based on the original TAM results [39], BIU is positively influenced by PU and ATU. In this study BIU is defined as a user who has a strong intention to use mgovernment applications. Positive ATU is defined as a user who wants to use m-government applications. PU is defined as a user who thinks that his or her job will be more productive and efficient by using m-government applications. In addition, BIU of e-learning is positively influenced by PEU [47]. In this study, PEU is defined as the degree to which a user believes that using m-government applications does not need much effort. Consequently, the hypotheses regarding TAM constructs in this study are:

H1: Perceived usefulness (PU) will have a positive significant influence on behavioural intention to use (BIU) mgovernment applications.

$\mathrm{H} 2$ : Attitude towards use (ATU) will have a positive significant influence on behavioural intention to use (BIU) mgovernment applications.

H3: Perceived ease of use (PEU) will have a positive significant influence on behavioural intention to use (BIU) mgovernment applications.

2) Hypotheses for relationships between the external factors and BIU: Trust plays a key role in new technology adoption because it impacts on users' intentions [48], [49]. Trust also has a strong positive influence on the adoption of $\mathrm{m}$ - commerce [50]. In addition, trust has a positive effect on users' intentions to use m-government services [20]. Consequently, the following is hypothesised:

H4: Perceived trustworthiness (TRU) will have a positive significant influence on behavioural intention to use (BIU) mgovernment applications.

In this study, perceived security includes perceived privacy. It has been claimed that security is very important in new technology adoption because users do not use these technologies if they are not perceived to be safe [51]. A previous study [52] found that security and privacy play a key role in m-government adoption. Security also has a positive impact on intention to use tourism m-payment systems [53] and is a key factor in the use of mobile banking [54]. Consequently, the following is hypothesised:

H5: Perceived security (SEC) will have a positive significant influence on behavioural intention to use (BIU) mgovernment applications.

In Jordan, a lack of awareness among citizens prevented egovernment adoption, resulting in the need for increased citizen awareness [55]. Awareness is also an important factor in new technology adoption, especially m-government adoption [33]. A recent study [56] found that a positive relationship between awareness and internet banking adoption. Another study [57] showed that awareness had a positive influence on the intention to adopt e-government in Bahrain. Consequently, the following is hypothesised:

H6: Awareness (AWAR) will have a significant positive influence on behavioural intention to use (BIU) m-government applications.

\section{F. Summary}

This study will address three existing problems:

1) To date, there have been insufficient empirical studies to identify and measure the factors that influence users' intentions to use m-government applications in Saudi Arabia.

2) To date, there have been insufficient empirical studies to measure Saudi citizens' attitudes towards using mgovernment applications.

3) To date, there have been insufficient empirical studies to validate and examine the applicability of TAM, with some modifications, in the Saudi m-government context. 


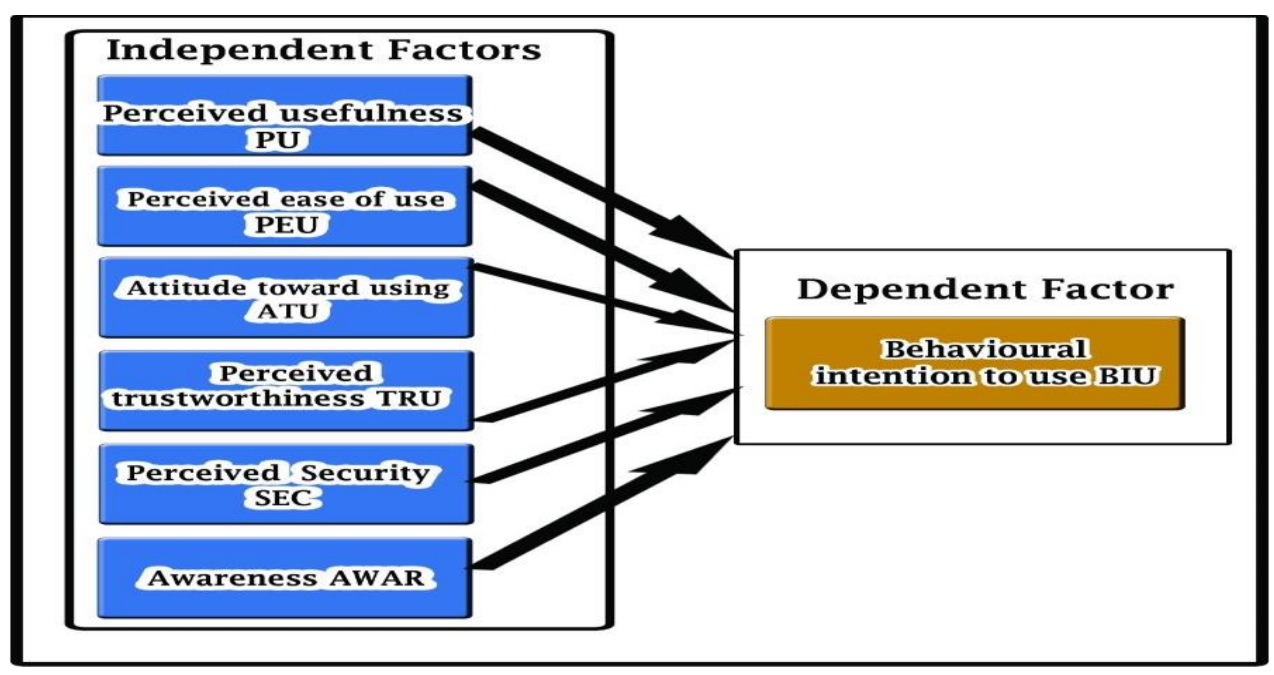

Fig. 2. Research model for this study.

\section{RESEARCH METHOD}

This study used quantitative methods to determine the impacts of the independent factors on BIU of m-government applications in Saudi Arabia. The researcher used a selfadministered questionnaire to collect data from participants. Researchers often use questionnaires to identify factors that influence the adoption and acceptance of new technology, taking advantage of the low cost and limited time required [58]. Questionnaires also improve ease of access to participants and increase the likelihood of receiving truthful responses [33].

\section{A. Questionnaire}

Balnaves and Caputi [59] warned that words used in questionnaires can affect results; thus, researchers should be careful about their wording. In particular, they should use easy and clear language to ensure participants' understanding [40]. The study questionnaire was validated by its use and adoption in previous studies [20], [38], [39], [60]-[62] and was modified to suit the m-government context. To ensure clarity and avoid errors, the questionnaire was first tested by English language experts. As the respondents were native Arabic speakers, they received an Arabic copy of the questionnaire, which was sent to expert translators to ensure accuracy and clarity of the responses.

\section{B. Instrument}

The questionnaire consisted of four parts. Part one focussed on demographic characteristics. Parts two and three listed items related to TAM model constructs and external factors. Parts two and three also sought to measure participants' attitudes toward using m-government applications in Saudi Arabia and to measure the factors that influence users' intentions to use mgovernment applications. Finally, part four allowed participants to make their own comments and offered research results to those who left an email address. All TAM constructs and external factors were measured at seven levels on a Likert-type scale. Participants were asked to choose from $7=$ Strongly Agree, 6 = Moderately Agree, $5=$ Slightly Agree, $4=$ Neutral, 3 = Slightly Disagree, $2=$ Moderately Disagree and $1=$ strongly Disagree.

\section{Data Collection}

In this study, the target population was Saudi citizens (male and female) who have internet access. This study used probability sampling (random sampling), which is defined as a technique in which "there is an equal chance to be selected and participate between units (e.g. persons, cases) in the population and that selections are made independently" [63]. However, given that the number of Saudi citizens was more than 20 million in 2015 [64], it was difficult to give all Saudi citizens an equal chance to participate in this study due to time limitations and associated costs. Consequently, researchers focused on Saudi citizens using email groups, Twitter, social networks and Facebook, and distributed an online link to a questionnaire to these users. This approach was used to obtain the minimum sample size required for this study, which was calculated to be 384 participants.

This allowed the researcher to collect data from a large population while providing clear instructions on how to complete the questionnaire. To improve the response rate, the researcher adopted some techniques recommended in [65], in particular, that the questionnaire is as brief as possible, the first page of the questionnaire introduces the researchers and explains the significance of the study and its objectives. Each week, the researcher sent follow-up reminders about the questionnaire to participants through email and social networks.

More than 1600 questionnaires were distributed and 1,152 (72\%) of the 1600 questionnaires were returned. Of those, 370 (23\%) questionnaires were incomplete and 782 (48\%) included full responses. The full response rate of $48 \%$ was considered adequate because a $30 \%$ response rate is considered acceptable when analysing surveys [66].

\section{Ethical Considerations}

The study was conducted anonymously, transparently, and with the promise of no harm. The participants had the right of easy access to research results and the choice (non-compulsory) of whether to participate. They were also under no obligation to fully complete the questionnaire. Institutional ethical approval was provided by Griffith University. 


\section{DATA ANALYSIS}

\section{A. Demographics}

As shown in Table 1, the vast majority of participants who completed this questionnaire were male 613 (78.4 \%) compared to $169(21.6 \%)$ females.

TABLE. I. DEMOGRAPHIC INFORMATION FOR PARTICIPANTS WHO FULLY COMPLETED THE QUESTIONNAIRE

\begin{tabular}{|c|c|c|c|}
\hline \multicolumn{2}{|c|}{ Information } & $\begin{array}{c}\text { Number of } \\
\text { participants }\end{array}$ & $\begin{array}{c}\text { Percentage } \\
\text { of sample }\end{array}$ \\
\hline \multirow[t]{3}{*}{ Gender } & Male & 613 & $78.4 \%$ \\
\hline & Female & 169 & $21.6 \%$ \\
\hline & $\begin{array}{l}\text { Total number of } \\
\text { participants }\end{array}$ & 782 & $100 \%$ \\
\hline \multirow{6}{*}{ Age } & $<30$ & 274 & $35 \%$ \\
\hline & $30<40$ & 362 & $46.3 \%$ \\
\hline & $40<50$ & 112 & $14.3 \%$ \\
\hline & $50<60$ & 30 & $3.8 \%$ \\
\hline & 60 or more & 4 & $0.5 \%$ \\
\hline & $\begin{array}{l}\text { Total number of } \\
\text { participants }\end{array}$ & 782 & $100 \%$ \\
\hline \multirow{3}{*}{$\begin{array}{l}\text { Where participants } \\
\text { resided }\end{array}$} & City & 638 & $81.6 \%$ \\
\hline & Village & 144 & $18.4 \%$ \\
\hline & $\begin{array}{l}\text { Total number of } \\
\text { participants }\end{array}$ & 782 & $100 \%$ \\
\hline \multirow[t]{6}{*}{ Qualifications } & High School & 105 & $13.4 \%$ \\
\hline & Diploma & 107 & $13.7 \%$ \\
\hline & Bachelor & 375 & $48 \%$ \\
\hline & Postgraduate & 187 & $23.9 \%$ \\
\hline & Other & 8 & $1 \%$ \\
\hline & $\begin{array}{l}\text { Total number of } \\
\text { participants }\end{array}$ & 782 & $100 \%$ \\
\hline \multirow{6}{*}{ Occupation } & Students & 97 & $12.4 \%$ \\
\hline & $\begin{array}{l}\text { Working in a } \\
\text { government } \\
\text { organization }\end{array}$ & 500 & $63.9 \%$ \\
\hline & $\begin{array}{l}\text { Working in the } \\
\text { private sector }\end{array}$ & 98 & $12.5 \%$ \\
\hline & Businessperson & 18 & $2.3 \%$ \\
\hline & Other & 69 & $8.8 \%$ \\
\hline & $\begin{array}{l}\text { Total number of } \\
\text { participants }\end{array}$ & 782 & $100 \%$ \\
\hline \multirow[t]{6}{*}{$\begin{array}{l}\text { Experience with m- } \\
\text { government } \\
\text { applications }\end{array}$} & $\begin{array}{l}\text { Have not used m- } \\
\text { government } \\
\text { applications }\end{array}$ & 187 & $23.9 \%$ \\
\hline & Less than one year & 157 & $20.1 \%$ \\
\hline & $\begin{array}{l}\text { More than one } \\
\text { year/less than two } \\
\text { years }\end{array}$ & 125 & $16 \%$ \\
\hline & $\begin{array}{l}\text { More than two } \\
\text { years/less than three } \\
\text { years }\end{array}$ & 137 & $17.5 \%$ \\
\hline & Three years or more & 176 & $22.5 \%$ \\
\hline & $\begin{array}{l}\text { Total number of } \\
\text { participants }\end{array}$ & 782 & $100 \%$ \\
\hline
\end{tabular}

Nearly half of the respondents were aged 30-39 (46.3\%, 362 ). In contrast, the smallest age group of respondents was those aged 60 or more $(0.5 \%, 4)$.

Most participants $(81.6 \%, 638)$ lived in cities. More than $70 \%$ (562) had university qualifications while almost all others had attended high school $(13.4 \%, 105)$ or had completed a diploma $(13.7 \%, 107)$.

Most $(64 \%, 500)$ worked in government organisations, with students $(12.4 \%, 97)$ and private sector workers $(12.5 \%, 98)$ being common among participants. Very few business people $(2.3 \%, 18)$ completed the questionnaire. About $75 \%$ (595) of participants had previously used m-government applications. Table 1 presents the rest of the demographic information.

\section{B. Measurement Scale Analysis}

1) Validity: Construct validity is defined as the extent to which items in an instrument reflect the theoretical construct. Construct validity is also defined as the extent to which one can measure the concept that should be measured [67]. In the same vein, it has been claimed that validity seeks to measure the extent to which the instrument achieves its goals [68], [69]. Factor analysis is a popular analytic tool to measure construct validity [69].

In this study, exploratory factor analysis (EFA) and confirmatory factor analysis (CFA) were conducted to measure construct validity by splitting the sample randomly, using SPSS, into two samples. It has been claimed that "This approach allows for cross validation of the final factor structure in a subsample that is relatively independent from efforts to refine the item pool. This reduces capitalizing on samplespecific variance" [70]. One-half of the sample $(n=388)$ was used in an EFA to explore the scale's underlying factor structure. It was then used to measure the reliability of the instrument using Cronbach's alpha. The other half $(\mathrm{n}=394)$ was used in a CFA to test the goodness-of-fit of the revealed factor structures [71].

\section{a) Exploratory Factor analysis (EFA)}

Exploratory factor analysis (EFA) is used for several purposes, including developing and testing instruments [72]. According to Field [73], "this technique has three main uses: (1) to understand the structure of a set of variables, (2) to construct a questionnaire to measure an underlying variable, (3) to reduce a data set to a more manageable size while retaining as much of the original information as possible". While all factors in this study were adopted from previous studies based on a literature review, EFA was considered appropriate because these factors have not been previously applied empirically in an m-government context in Saudi Arabia.

Kaiser-Meyer-Olkin (KMO) was examined to assess the adequacy of sampling. It has been confirmed that the values of KMO correlation for EFA analysis results are adequate if above 0.6 to 0.7 [68]. Furthermore, Field [74] asserted that KMO values less than 0.5 indicate unacceptable sampling adequacy while those greater than 0.9 indicate excellent sampling adequacy. Consistent with this, de Vaus [75] asserted that $\mathrm{KMO}$ values should be above 0.5 . 
EFA requires two important steps, namely, 1) factor extraction; and 2) factor rotation. Therefore, a Principal component analysis (PCA) was used as extraction method to determine the factors that explain the structure of the variables [76] and to obtain an empirical abstraction of the number of factors and to identify the factors in the data [77]. A Varimax rotation was conducted to maximise the orthogonality (independence) of separate factors [78]. The Varimax rotation also provides clearer separation of factors [79]. There are some criteria regarding factor loadings after Varimax rotation. It has been asserted that factor loadings less than 0.4 should be discarded because they are too low [73], [79]. In this study, any factor loading value less than 0.5 was excluded to assure that all items have practical significance [79].

EFA was conducted in this study with one split sample $(\mathrm{n}=$ 388) with the following results. The KMO value for an EFA that includes all constructs was 0.932 , which indicates excellent sampling adequacy for this study. Moreover, Bartlett's Test of Sphericity (Approx. Chi-Square $=10163.185$ ) was highly significant $(\mathrm{p}<0.001)$ and is consistent with there being a strong relationship between items included in the analysis [73]. These findings support the factorability of the EFA conducted for these factors [73], [79], [80]. The seven factors in the rotated component matrix: perceived usefulness PU, attitude toward using ATU, perceived ease of use PEU, behavioural intention to use BIU, perceived trustworthiness TRU, perceived security SEC and awareness AWAR are presented in Table 2.

TABLE. II. ROTATED COMPONENT MATRIX

\begin{tabular}{|c|c|c|c|c|c|c|c|}
\hline & \multicolumn{7}{|c|}{ Component } \\
\hline & 1 & 2 & 3 & 4 & 5 & 6 & 7 \\
\hline PU1 & & 0.586 & & & & & \\
\hline PU2 & & 0.740 & & & & & \\
\hline PU3 & & 0.775 & & & & & \\
\hline PU4 & & 0.813 & & & & & \\
\hline PU5 & & 0.752 & & & & & \\
\hline PU6 & & 0.688 & & & & & \\
\hline ATU1 & & & & & & 0.835 & \\
\hline ATU2 & & & & & & 0.804 & \\
\hline ATU3 & & & & & & 0.859 & \\
\hline PEU1 & 0.732 & & & & & & \\
\hline PEU2 & 0.750 & & & & & & \\
\hline PEU3 & 0.798 & & & & & & \\
\hline PEU4 & 0.739 & & & & & & \\
\hline PEU5 & 0.755 & & & & & & \\
\hline PEU6 & 0.669 & & & & & & \\
\hline BIU1 & & & & & & & 0.740 \\
\hline BIU2 & & & & & & & 0.694 \\
\hline BIU3 & & & & & & & 0.597 \\
\hline TRU1 & & & & 0.697 & & & \\
\hline TRU2 & & & & 0.664 & & & \\
\hline TRU3 & & & & 0.765 & & & \\
\hline TRU4 & & & & 0.714 & & & \\
\hline TRU5 & & & & 0.697 & & & \\
\hline SEC1 & & & 0.761 & & & & \\
\hline SEC2 & & & 0.839 & & & & \\
\hline SEC3 & & & 0.850 & & & & \\
\hline SEC4 & & & 0.747 & & & & \\
\hline SEC5 & & & 0.810 & & & & \\
\hline AWAR1 & & & & & 0.846 & & \\
\hline AWAR2 & & & & & 0.856 & & \\
\hline AWAR3 & & & & & 0.862 & & \\
\hline
\end{tabular}

In summary, the EFA test returned a seven-components solution that explained $76.746 \%$ of the cumulative variance, with a KMO measure of sampling of 0.932 , which is consistent with these items being highly suitable for factor analysis.

Extraction Method: Principal Component Analysis.

Rotation Method: Varimax with Kaiser Normalization.

\section{b) Reliability}

According to Drost [81], "reliability is consistency of measurement or stability of measurement over a variety of conditions in which basically the same results should be obtained". After identifying the scale structure via EFA, the reliability of the instrument was evaluated using Cronbach's alpha on the half-sample used for the EFA $(n=388)$. Sekaran [66] asserted that internal consistency is a very common measure of reliability in information systems (IS). Internal consistency relates to consistent responses for items to scale a single measurement [82]. Reliability can be divided into four ranges: values of up to 0.50 have low reliability; from 0.50 to 0.70 moderate reliability; from 0.70 to 0.90 high reliability; and from 0.90 and above excellent reliability [83]. It has been noted that Cronbach's alpha values should be 0.7 or higher to conclude that the internal consistency is reliable [79]. The results presented in Table 3 indicate that all values were higher than 0.70 and most were nearly 0.9 , which is considered excellent reliability. Furthermore, when all items were entered at the same time, the overall reliability for this instrument was 0.947, which is considered excellent. Therefore, the results of this study can be considered reliable in the Saudi mgovernment context.

\section{a) Overview SEM}

A Structural Equation Model (SEM) comprises a collection of statistical methods that can be used to clarify and analyse relationships between variables [84]. SEM has two components, the measurement model and the structural model [79], [82], [85]. SEM can also test theoretical models [79]. Moreover, SEM tests hypotheses between variables by measuring the magnitude of the path of the coefficient between variables [86]. Gefen, Straub, and Boudreau [87] recommended the use of SEM in IT/IS studies, especially in behavioural studies.

TABLE. III. RELIABILITY COEFFICIENT VALUES

\begin{tabular}{|l|l|l|l|}
\hline Constructs & $\begin{array}{l}\text { Number of } \\
\text { items }\end{array}$ & $\begin{array}{l}\text { Cronbach Alpha } \\
\text { reliability }\end{array}$ & Comments \\
\hline $\begin{array}{l}\text { Perceived Usefulness } \\
\text { (P U) }\end{array}$ & 6 & 0.927 & $\begin{array}{l}\text { Excellent } \\
\text { reliability }\end{array}$ \\
\hline $\begin{array}{l}\text { Attitude toward using } \\
\text { (ATU) }\end{array}$ & 3 & 0.907 & $\begin{array}{l}\text { Excellent } \\
\text { reliability }\end{array}$ \\
\hline $\begin{array}{l}\text { Perceived Ease of Use } \\
\text { (PEU) }\end{array}$ & 6 & 0.900 & $\begin{array}{l}\text { Excellent } \\
\text { reliability }\end{array}$ \\
\hline $\begin{array}{l}\text { Behavioural intention } \\
\text { to use (BIU) }\end{array}$ & 3 & 0.816 & $\begin{array}{l}\text { High } \\
\text { reliability }\end{array}$ \\
\hline $\begin{array}{l}\text { perceived } \\
\text { trustworthiness (TRU) }\end{array}$ & 5 & 0.894 & $\begin{array}{l}\text { Excellent } \\
\text { reliability }\end{array}$ \\
\hline $\begin{array}{l}\text { perceived security } \\
\text { SEC) }\end{array}$ & 5 & 0.914 & $\begin{array}{l}\text { Excellent } \\
\text { reliability }\end{array}$ \\
\hline Awareness (AWAR) & 3 & 0.962 & $\begin{array}{l}\text { Excellent } \\
\text { reliability }\end{array}$ \\
\hline Overall reliability & $\mathbf{3 1}$ & 0.947 & $\begin{array}{l}\text { Excellent } \\
\text { reliability }\end{array}$ \\
\hline
\end{tabular}


SEM describes the relationships between variables clearly using graphic diagrams [82]. Confirmatory factor analysis (CFA) is used to measure the model by assessing the indicators used to measure the latent variables [85]. In this study, the SEM procedure, Confirmatory Factor Analysis, was conducted via SPSS AMOS 24. It measured the validity of the factor structure of half the sample $(n=394)$ by using CFA. SPSS AMOS 24 was then used to assess relationships between variables via a structural model that used the entire sample $(\mathrm{n}=$ 782), as reported later.

\section{b) Measurement model using CFA}

CFA is a SEM analysis technique [84], [88]. The main reason for using CFA is to measure the construct validity of the hypothesised factor structure [79]. Harrington [89] claimed that there are four reasons for conducting CFA: testing method effects, construct validation, psychometric evaluation of measures, and testing measurement invariance. CFA is also a suitable technique to measure the validity of scales [90]. CFA focuses on the construct's validity and the model's overall fit. It assesses the measurement theory by using empirical evidence of the validity of items [84]. Two aims of CFA are to examine the relationship between a group of continuous latent variables and a group of observed variables [91]. In addition, CFA is conducted to define the goodness-of-fit between collected data and a model used in another study [92]. Finally, CFA is widely used to analyse latent variables [93].

Fit indices used to assess the fit of the measurement model include: CMIN (minimum discrepancy), Chi-Square $\left(\chi^{2}\right)$, Goodness-of-fit (GFI) and adjusted goodness of fit (AGFI), Comparative fit index (CFI), Incremental fit index (IFI), and the Root Mean Square Error Approximation (RMSEA) [84]. Table 4 summarizes all criteria for model assessment.

AMOS 24 was used to conduct CFA for all constructs to assess the model fit using half of the study sample $(n=394)$ (Fig. 3). The results reveal that the model has acceptable fit values and is valid (Table 5). Consequently, the model is fit and valid in the Saudi m-government context.

\section{Model Assessment}

1) Assessment of the hypotheses: The structural equation model $($ SEM) for the entire sample $(n=782)$ examined six hypotheses via Maximum Likelihood, by calculating the significance and the strength of each pathway Fig. 4. Only the significant results are reported here.
TABLE. IV. SUMMARY OF CRITERIA FOR MODEL ASSESSMENT

\begin{tabular}{|l|l|l|}
\hline Fit indices & Criteria & References \\
\hline$\chi^{2} / \mathrm{df}(\mathrm{CMIN} / \mathrm{df})$ & $\begin{array}{l}<3 \text { is a good fit; }<5 \text { is } \\
\text { an acceptable fit }\end{array}$ & [84], [88], [94] \\
\hline RMSEA & $\begin{array}{l}<0.05 \text { is an excellent } \\
\text { fit; }<0.08 \text { is a good } \\
\text { fit; }<0.1 \text { is an } \\
\text { acceptable fit. }\end{array}$ & [88], [95] \\
\hline GFI, AGFI, IFI and & $\begin{array}{l}\text { AGFI }>0.80 \text { is a good } \\
\text { fit; GFI, AGFI, IFI } \\
\text { and CFI }>0.95 \text { is an } \\
\text { excellent fit; }>0.90 \text { is } \\
\text { a good fit; }>0.80 \text { is } \\
\text { an acceptable fit. }\end{array}$ & [84], [87], [96]-[98] \\
\hline
\end{tabular}

TABLE. V. RESUltS OF THE MODEL GOODNESS-OF-FIT INDICES By CFA

\begin{tabular}{|l|l|l|}
\hline Fit indices & Result & Comment \\
\hline$\chi^{2} / \mathrm{df}(\mathrm{CMIN} / \mathrm{df})$ & 1.987 & Good fit \\
\hline RMSEA & 0.050 & Excellent fit \\
\hline GFI & 0.886 & Acceptable fit \\
\hline AGFI & 0.857 & Good fit \\
\hline IFI & 0.960 & Excellent fit \\
\hline CFI & 0.959 & Excellent fit \\
\hline
\end{tabular}

The results revealed some non-significant paths, including those involving perceived ease of use, perceived security and awareness. Therefore, H3, H5 and H6 are not supported in the Saudi m-government context. Significant paths between factors and BIU were found for perceived usefulness, attitude toward using and perceived trustworthiness. Therefore, hypotheses $\mathrm{H} 1$, $\mathrm{H} 2$ and $\mathrm{H} 4$ are confirmed and supported in the Saudi mgovernment context:

a) Perceived usefulness (PU) has a significant positive influence on Behavioural intention to use $(\beta=0.266, \mathrm{P}<$ 0.001) and, accordingly, $\mathrm{H} 1$ is supported.

b) Attitude toward using (ATU) has a significant positive influence on Behavioural intention to use $(\beta=0.484, \mathrm{P}<$ 0.001 ) and, accordingly, $\mathrm{H} 2$ is supported.

c) Perceived trustworthiness (TRU) has a significant positive influence on Behavioural intention to use $(\beta=0.247$, $\mathrm{P}<0.001$ ) and, accordingly, H4 is supported. 


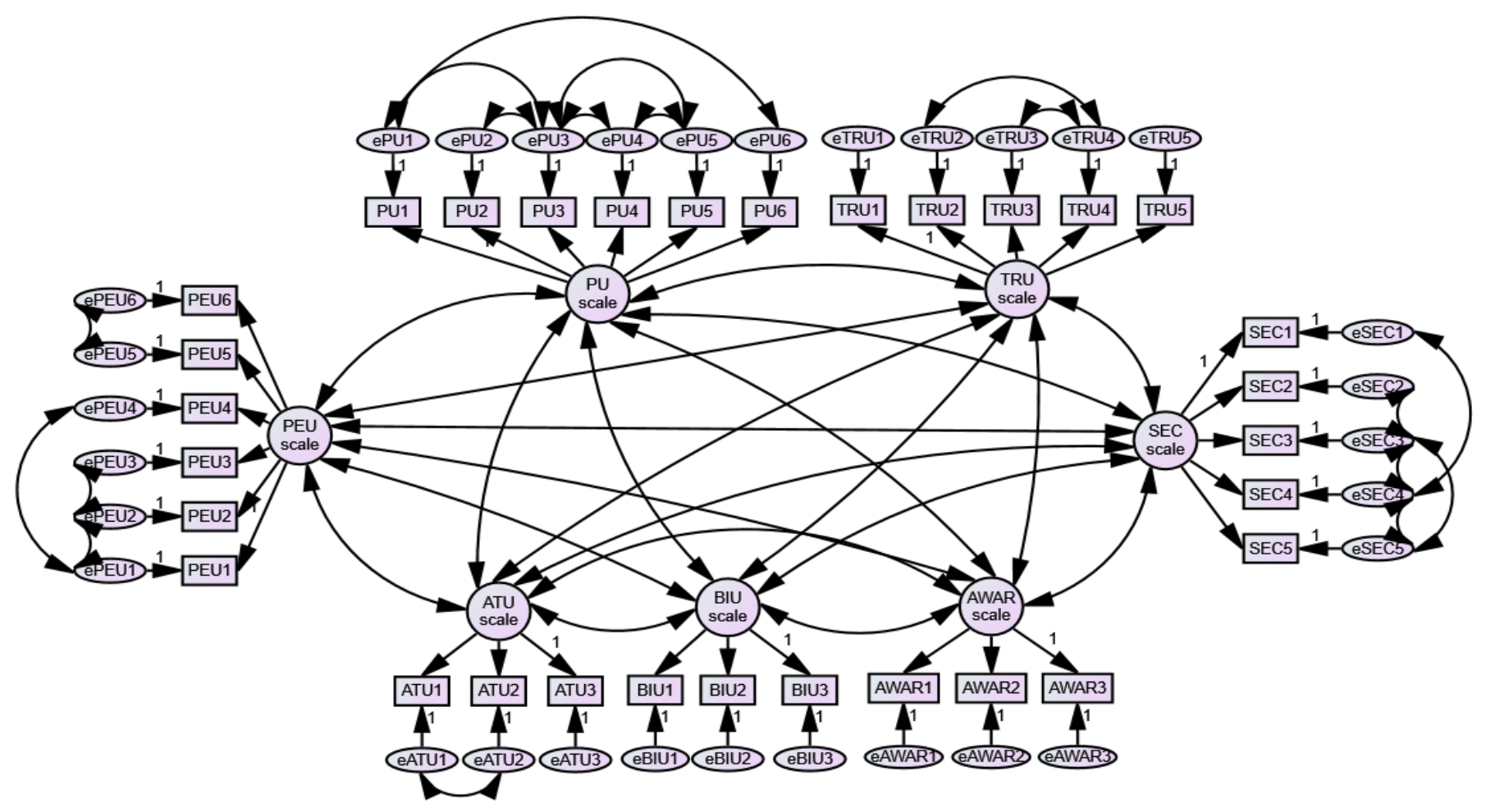

Fig. 3. CFA for all constructs.

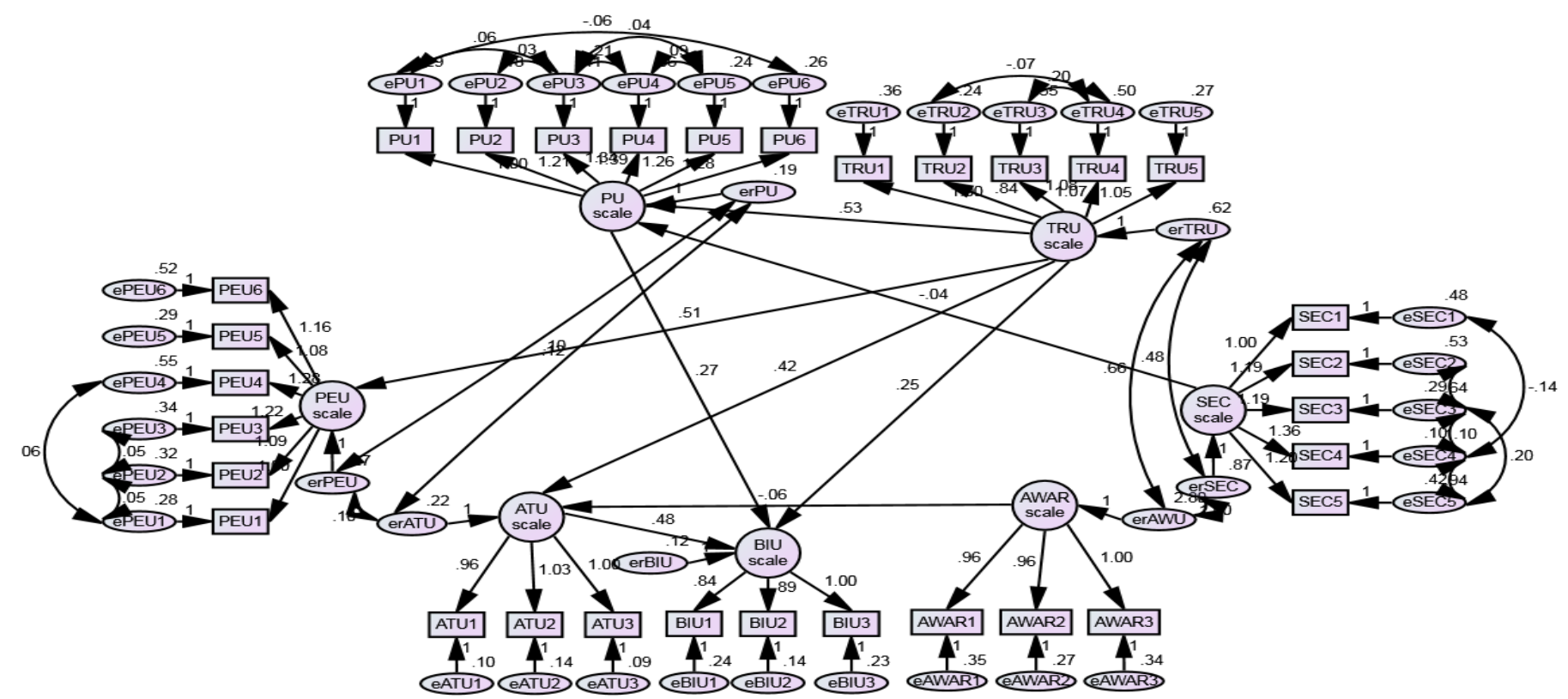

Fig. 4. Structural model for standardized path coefficients.

\section{DISCUSSION}

The results of this study demonstrated that all TAM construct factors, except perceived ease of use, have a significant positive influence on BIU which is compatible with the original TAM outcomes [39]. This unusual outcome is also supported by [42], where PEU did not affect intention to use elearning in Korea. Another study [99] found that PEU had no 
influence on intention to use e-commerce in Indonesia. Other studies have stated that ease of use was not a strong factor for measuring the intention to use new systems [39], [100]. Davis [39] stated that ease of use is better for predicting usefulness rather than intention to use. These results indicate that users accepted the difficulty in using m-government applications which have already been released. In other words, they do not care about ease of use, they are focused on obtaining the services they need, regardless of whether this is easy or not. It goes without saying that decision makers in Saudi government who are providers of m-government applications for citizens, especially Yesser, should provide the services via applications in a user friendly way with clear and simple to follow instructions to encourage the users to use and operate these applications. In fact, ease of use of applications is considered an advantage in general, although the result of the current research revealed that it was not considered important. Also, decision makers in the Saudi government who provide mgovernment applications for citizens, especially Yesser, should consider perceived usefulness when providing these applications because the results of this and previous studies show this factor to be very important to users.

The preliminary analysis and data screening revealed that participants tended to give high ratings to items, usually in the moderately agree (6) to strongly agree (7) interval, particularly for items related to ATU. For this reason, both the items and the associated scale scores were somewhat negatively skewed. Closer observation of the ratings suggested that few of the participants were prepared to give negative ratings, and relatively few were prepared to even give a neutral rating. In effect, the majority of the participants were using a four-point scale that utilised the four main positive responses $(4=$ Neutral, $5=$ Slightly Agree, $6=$ Moderately Agree and $7=$ Strongly Agree). Previous results showed that ATU has a significant positive influence on BIU. This means that the sample population has a positive attitude toward using mgovernment applications and intends to use these applications in the future. Therefore, the majority of participants believe that using m-government applications is a good and positive idea. This outcome is supported by a study [101] which found that the majority of participants (male and female) wanted to use government services via mobile devices in Saudi Arabia. Results of the current study show that most participants have a positive attitude toward using $\mathrm{m}$-government applications. This suggests that citizens will use m-government without any resistance to change and will support the government decision to provide these services. Therefore, decision makers in Saudi government, especially Yesser, who are providers of $\mathrm{m}$ government applications for citizens, should continue to expand the provision of services via applications.

The outcomes of this study revealed that perceived trustworthiness has a positive significant influence on BIU of m-government applications. This suggests that most participants in this study trust m-government applications and their benefits because these applications have been released by the government. This outcome is consistent with the literature showing that when trust in the internet and government increases, increases in the intention to use e-government services also occur [35]. Carter and Weerakkody [102] found that trust has a positive impact on e-government services in the UK. The study by Alrowili, Alotaibi and Alharbi [20] supports this outcome, finding that perceived trust had a direct positive effect on users' intentions to use m-government services in Saudi Arabia. The recommendation for decision makers in the Saudi Government who are providers of m-government applications for citizens, especially Yesser, is that they should try to build trust with Saudi citizens to encourage them to use services via m-government applications. Also, applications designers and developers should build trustworthy applications, because trust has been shown to be a very important factor for citizens in their use of m-government application.

Perceived security had no influence on BIU. This outcome might indicate that participants do not care about security because they trust applications released by the government. Security may also not be not an issue for the majority of participants who intend to use m-government applications, because they have been using the internet for a long time and are aware of security and privacy problems [103]. This outcome is supported by several studies. Ratten [104] found that privacy concerns do not impact on purchase intentions of cloud computing services in India and the USA. A later study [105], found that security is not much of a concern for consumers who intend to adopt cloud computing in the USA or Australia. More recently, it was found that increased security does not lead to increased intention to use online channels for purchase in Jordan [103]. The recommendation for decision makers in the Saudi government who are providers of $\mathrm{m}$ government applications for citizens, especially Yesser, is that they should continue to be concerned about this factor and try to increase the level of perceived security in applications, although this is not a concern in the current research study. Also, they should provide services via secure applications to encourage users to use these applications. In fact, increased perceived security in applications is considered to be an advantage. Therefore, application designers and developers should build these applications, maintaining their security. Also, the Saudi government should issue a law to protect users if they have problems regarding security and privacy of using m-government applications.

The outcomes of this study revealed that awareness does not influence BIU. This outcome is incompatible with some previous empirical studies. For example, it has been found that awareness has a positive influence on intention to adopt $\mathrm{m}$ banking [106]. However, the results of this study indicate that the majority of participants have a low level of awareness about m-government applications because they do not have knowledge or information about these applications. This may indicate that government sectors do not raise awareness about their services to citizens. Therefore, several other studies have suggested that government should increase the rate of awareness among citizens by using media such social networks, television advertisements and newspapers [58], [107]. The recommendation for decision makers in the Saudi government who are providers of m-government applications for citizens, especially Yesser, is that they should act on the concern about this factor and try to distribute information and knowledge for citizens about m-government applications and their benefits via the media to inform citizens about these apps. 


\section{CONCLUSION AND IMPLICATIONS}

The applicability of the modified TAM model to fulfill the study objectives was evaluated by measuring the influence of six independent factors (PU, ATU, PEU, TRU, SEC and AWAR) on users' intentions to use m-government applications in Saudi Arabia.

The study identified the influential factors as being ATU, PU and TRU. The model was modified to include these factors and tests revealed that the modified TAM model was suitable and fit for the Saudi m-government context. The results also showed that most participants had a positive attitude towards using $\mathrm{m}$-government applications.

The results of this study will help decision makers involved in e-government and m-government initiatives in Saudi Arabia to adapt m-government applications properly and successfully by acknowledging and addressing the key influential factors. The modified model can be used in other countries to understand factors that influence users' intention to use mgovernment applications.

\section{DIRECTIONS FOR FUTURE WORK}

This study adopted the TAM model, with some modifications, to fulfil the study objectives by measuring the influence of six factors (PU, ATU, PEU, trust, security and awareness) on users' intention to use m-government applications in Saudi Arabia. In future research it would be better to incorporate TAM with other models such as DOI in order to examine the applicability of the incorporated model in the Saudi m-government context. This would lead to measuring and considering other factors which were not measured in this study but that may influence users' intention to use $\mathrm{m}$ government applications. Since this study focused on mG2C systems to explore and measure the factors that influence users' intentions to use m-government applications from citizens' perspectives, it has disregarded other types of $\mathrm{m}$ government such as m-government-to-government (mG2G), m-government-to-employee (mG2E) and m-government-tobusiness (mG2B). Future research should focus on one or more of these other types to explore and measure the factors that influence behavioural intention to use m-government applications. Changing the context between countries may also be a useful way to further develop and validate this model.

\section{REFERENCES}

[1] O. Alfarraj, Factors influencing the development of egovernment in Saudi Arabia: a qualitative investigation of the developers perspectives, School of Information and Communication Technology, Griffith University, Brisbane, Australia, 2013.

[2] O. Alfarraj and T. Alhussain, "Making Sense of E-Government development in Saudi Arabia: A Qualitative Investigation," paper presented at The Eighth International Conference on Forensic Computer Science, 2013.

[3] O. Alfarraj, T. Alhussain, and A. Abugabah, "Identifying the Factors Influencing the Development of eGovernment in Saudi Arabia: The Employment of Grounded Theory Techniques," International Journal of Information and Education Technology, vol. 3, no. 3, p. 319, 2013.

[4] S. Alghamdi and N. Beloff, "Innovative Framework for e-Government adoption in Saudi Arabia: A Study from the business sector perspective," International Journal of Advanced Computer Science and Applications, vol. 7, no. 1, pp. 655-664, 2016.
[5] J. Moon, From E-Government to M-Government?: Emerging Practices in the Use of Mobile Technology by State Governments. E-Government Series Texas, USA: IBM Center for The Business of Government, 2004.

[6] Althunibat, T. Alrawashdeh, and M. Muhairat, "The acceptance of using m-government services in Jordan," Journal of Theoretical and Applied Information Technology, vol. 63, no. 3, pp. 733-740, 2014.

[7] T. El Kiki, and E. Lawrence, "Government as a mobile enterprise Realtime, ubiquitous government," in Information Technology: New Generations, Third International Conference on , 2006. IEEE.

[8] O, Östberg, "A Swedish View on 'Mobile Government," paper presented at the International Symposium on E \& M-Government, Seoul, Korea, $<\quad$ http://www. statskontoret. se/upload/Publikationer/2003/2003128. pdf. 2003.

[9] M. Kumar, and O. Sinha, "M-government-mobile technology for egovernment," paper presented at the International conference on egovernment, India, 2007.

[10] Misra, "Make M-Government an Integral Part of E-Government: An Agenda for Action," Compendium, pp. 78-86, 2009.

[11] H. Sheng, and S. Trimi, "M-government: technologies, applications and challenges," Electronic Government, An International Journal, 5, no. 1, pp. $1-18,2008$

[12] Mengistu, H. Zo, and J. Rho, "M-Government: Opportunities and challenges to deliver mobile government services in developing countries," paper presented at the Fourth International Conference on Computer Sciences and Convergence Information Technology, 2009. IEEE.

[13] T. Ahmad, T, et al., "CURRENT REVIEW OF ICT AND MGOVERNMENT SERVICES IN SAUDI ARABIA," International Journal of Computer Engineering and Applications, vol. VII, no. II, pp. 71-77, 2014.

[14] CITC, Annual report. Communication and Infromation technology commission Saudi Arabia, 2015

[15] M. Khan, "Exploring the Push and Pull Drivers in M-Government Framework that Influence Acceptance of Services on Mobile Devices," International Journal of Computer Science and Network Security (IJCSNS), vol. 16, no. 2, p. 23, 2016.

[16] A. Baabdullah, O. Nasseef, and A. Alalwan, Consumer adoption of mobile government in the Kingdom of Saudi Arabia: The role of usefulness, ease of use, perceived risk and innovativeness, in IFIP International Federation for Information Processing. 2016. Switzerland: Springer International Publishing.

[17] A. Babullah, Y. Dwivedi, and M. Williams, "Saudi Citizens' Perceptions on Mobile Government (mGov) Adoption Factors," in UK Academy for information systems conference proceedings 2015. UK: Association for information systems AIS electronic library (AISeL).

[18] T. Alhussain, Factors Influencing the Adoption of Biometric Authentication in Mobile Government Security, in school of information and communication technology science. 2012, Griffith University: Brisbane, Australia.

[19] A. Alsenaidy, and T. Ahmad, A review of current state m-government in Saudi Arabia. 2012.

[20] T. Alrowili, M. Alotaibi, and M. Alharbi, "Predicting citizens' acceptance of M-government services in Saudi Arabia an empirical investigation," paper in the Proceedings of the 2015 Annual IEEE Systems Conference (SysCon), Marriott Pinnacle Vancouver, Vancouver, BC, Canada: IEEE, 2015.

[21] S. Alotaibi, and D. Roussinov, "A conceptual model for examining mobile government adoption in Saudi Arabia," in the Proceedings of The 15th European Conference on eGovernment ECEG, University of Portsmouth, 2015. Barcelona,Spain.

[22] M. Ntaliani, C. Costopoulou, and S. Karetsos, "Mobile government: A challenge for agriculture," Government Information Quarterly, vol. 25, no. 4, pp. 699-716, 2008.

[23] A. Al-Hadidi, and Y. Rezgui, "Adoption and diffusion of mGovernment: Challenges and Future Directions for Research," in Collaborative Networks for a Sustainable World,:Springer, 2010, pp. 8894. 
[24] A. Nava, and I. Dávila, "M-Government for Digital Cities: Value Added Public Services," in The Proceedings of the 1st European Mobile Government Conference, UK: Mobile Government Consortium International Pub., 2005.

[25] K. Assar, "M-government in Saudi Arabia," International Journal of Advanced Research in Computer Science and Software Engineering, vol. 5, no. 1, pp. 76-83, 2015.

[26] Y. Kim, et al., Architecture for implementing the mobile government services in Korea," in Conceptual modeling for advanced application domains. 2004, Springer. p. 601-612.

[27] A. Abanumy and P. Mayhew, "M-government implications for egovernment in developing countries: The case of Saudi Arabia," in EURO mGOV. 2005. Brighton, UK.

[28] L. Antovski, and M. Gusev, "M-government framework," in Euro mGov. 2005. Brighton, UK.

[29] H. Scholl, "The mobility paradigm in government theory and practice: A strategic framework," in Euro mGov. 2005. Brighton, UK.

[30] A. Jahanshahi, et al., "Comprehensive model of mobile government in Iran," Indian Journal of Science and Technology, vol. 4, no. 9, pp. 11881197, 2011.

[31] I. Snellen, and M. Thaens, "From e-government to m-government: towards a new paradigm in public administration," Working document, Erasmus University, Rotterdam, 2008.

[32] M. Alomari, H. Elrehail, and H. Al Shibly, "Mobile-Government: Challenges and Opportunities Jordan as Case study," International Journal of Business and Social Science, vol. 4, no. 12, pp. 244-250, 2013.

[33] A. Al-Hadidi, "Exploratory study on adoption and diffusion of $\mathrm{m}$ government services in the sultanate of oman," in School of Engineering. 2010, CARDIFF UNIVERSITY (UNITED KINGDOM).

[34] T. Ahmad, et al., "Current review of ICT and m-government services in Saudi Arabia," Int. J. Comput. Eng. Appl, vol. 7, no. 2, 2014.

[35] L. Carter, and F. Bélanger, "The utilization of e-government services: citizen trust, innovation and acceptance factors," Information systems journal, vol. 15, no.1, pp. 5-25, 2005.

[36] B. Dickerson, "Motivation factors impacting employee acceptance of new technology," in School of Business and Technology. 2013, Capella University: USA.

[37] F. Davis, "A technology acceptance model for empirically testing new end-user information systems: Theory and results," in School of Management. 1986, Massachusetts Institute of Technology: USA.

[38] S. Alharbi, and S. Drew, "Using the technology acceptance model in understanding academics' behavioural intention to use learning management systems," (IJACSA) International Journal of Advanced Computer Science and Applications, vol. 5, no.1, pp. 143-155, 2014.

[39] F. Davis, "Perceived Usefulness, Perceived Ease of Use, and User Acceptance of Information Technology," MIS Quarterly, vol. 13, no. 3, pp. 319-340, 1989.

[40] O. Al-Hujran, M. Al-dalahmeh, and A. Aloudat, "The role of national culture on citizen adoption of eGovernment services: An empirical study," Electronic Journal of E-government, vol. 9, no. 2, pp. 93-106, 2011.

[41] Al-Adwan, A., A. Al-Adwan, and J. Smedley, Exploring students acceptance of e-learning using Technology Acceptance Model in Jordanian universities. International Journal of Education and Development using Information and Communication Technology, vol. 9, no. 2, pp. 4-18, 2013.

[42] S. Park, "An Analysis of the Technology Acceptance Model in Understanding University Students' Behavioral Intention to Use eLearning," Educational Technology \& Society, vol. 12, no. 3, pp. 150$162,2009$.

[43] P. Chau, "An empirical assessment of a modified technology acceptance model," Journal of management information systems, vol. 13, , pp. 185204, 1996.

[44] Q. Ma, and L. Liu, "The no. 2 acceptance model: A meta-analysis of empirical findings," Journal of Organizational and End User Computing (JOEUC), vol. 16, no.1, pp. 59-72, 2004.
[45] J. Moon, and Y. Kim, "Extending the TAM for a World-Wide-Web context," Information \& Management, vol. 38, no. 4), pp. 217-230, 2001.

[46] K. Al-Busaidi, and H. Al-Shihi, "Instructors' Acceptance of Learning Management Systems: A Theoretical Framework," Communications of the IBIMA 2010. 2010.

[47] C. Ong, J. Lai, and Y. Wang, "Factors affecting engineers' acceptance of asynchronous e-learning systems in high-tech companies," Information \& management, vol.41, no. 6), pp. 795-804, 2004.

[48] P. Palvia, "The role of trust in e-commerce relational exchange: A unified model, "Information \& Management, vol. 46, no. 4, pp. 213-220, 2009.

[49] D. Gefen, and D. Straub, "Managing user trust in B2C e-services, Eservice Journal, vol. 2, no. 2, pp. 7-24, 2003.

[50] T. Wei, et al., "What drives Malaysian m-commerce adoption? An empirical analysis," Industrial Management \& Data Systems, vol. 109, no. 3, pp. 370-388, 2009.

[51] T. Teo, S. Srivastava, and L. Jiang, "Trust and electronic government success: An empirical study," Journal of Management Information Systems, vol. 25, no. 3, pp. 99-132, 2008.

[52] A. Chang, and P. Kannan, "Preparing for wireless and mobile technologies in government," E-, pp. 345-393, 2003.

[53] R. Peng, L. Xiong, and Z. Yang, "Exploring tourist adoption of tourism mobile payment: An empirical analysis," Journal of Theoretical and Applied Electronic Commerce Research, vol. 7, no. 1, pp. 21-33, 2012.

[54] M. Mahad, et al., "Factor Affecting Mobile Adoption Companies in Malaysia," International Journal of Economics and Financial 5, pp. 8491, 2015.

[55] M. Alomari, "Predictors for Successful E-government Adoption in the Hashemite Kingdom of Jordan: The Deployment of an Empirical Evaluation Based on Citizen-Centric Perspectives", in International Business and Asian studies. 2011, Griffith University: Brisbane, Australia.

[56] S. Kumar and S. Madhumohan, "Internet banking adoption in India," Journal of Indian Business Research, vol. 6, no. 2, pp. 155-169, 2014.

[57] M. Meftah, B. Gharleghi, and B. Samadi, "Adoption of E-Government among Bahraini Citizens," Asian Social Science, vol. 11, no. 4, pp. 141149, 2015.

[58] I. Abunadi, "Influence of Culture on e-Government Acceptance in Saudi Arabia," in School of Information and Communication Technology. 2012, Griffith University: Brisbane, Australia.

[59] M. Balnaves, and P. Caputi, Introduction to Quantitative Research Methods: An Investigative Approach. London: SAGE Publications, 2001.

[60] R. Alotaibi, K. Sandhu, and L. Houghton, "A Study of Service Users' Attitudes towards E-Government Initiatives in the Kingdom Of Saudi Arabia," (IJCSIT) International Journal of Computer Science and Information Technologies, vol. 5, no. 6, pp. 6892-6901, 2014.

[61] H. Al-Busaidi, "A model of intention to use mobile government services," in School of Management and Information Systems,Faculty of Business and Law. 2012, Victoria University: Australia.

[62] M. AL-Majali, "No more traditional stock market exchange: a study of internet trading service (ITS) in Jordan," Journal of Internet Banking and Commerce, vol. 17, no. 1, pp. 1-19, 2012.

[63] C. Teddlie, and F. Yu, "Mixed methods sampling a typology with examples," Journal of mixed methods research, vol. 1, no. 1, pp. 77-100, 2007.

[64] Stats. General Information about The Kingdom of Saudi Arabia. 2016 [cited 25 December 2016]; Available from: http://www.stats.gov.sa/en/4025.

[65] H. Alsaghier, "An investigation of critical factors affecting citizen trust in e-government: empirical evidence fron Saudi Arabia," in Information Communication, Technology. 2010, Griffith University. Brisbane,Australia.

[66] U. Sekaran, Research methods for business: a skill-building approach, vol. 4. New York; Great Britain: Wiley, 2003. 
[67] Bagozzi, R., Y. Yi, and L. Phillips, Assessing construct validity in organizational research. Administrative science quarterly, 1991. 36(3): p. 421-458.

[68] Netemeyer, R.G., W.O. Bearden, and S. Sharma, Scaling Procedures: Issues and Applications. 2003, Thousnad Oaks,CA: SAGE Publications.

[69] Turocy, P.S., Survey research in athletic training: the scientific method of development and implementation. Journal of Athletic Train, 2002. 37(suppl 4): p. 174-179.

[70] Dik, B., et al., Development and validation of the calling and vocation questionnaire (CVQ) and brief calling scale (BCS). Journal of Career Assessment, 2012. 20(3): p. 1-22.

[71] $\mathrm{Ng}, \mathrm{S}$., Validation of the 10-item Chinese perceived stress scale in elderly service workers: one-factor versus two-factor structure. BMC psychology, 2013. 1(9): p. 1-8.

[72] Osborne, J. and A. Costello, Best practices in exploratory factor analysis: Four recommendations for getting the most from your analysis. Practical assessment, research \& evaluation, 2005. 10(7): p. 1-9.

[73] Field, A., Discovering statistics using SPSS. 2nd ed. 2005, London: Sage Publication.

[74] Field, A., Discovering Statistics using IBM SPSS Statistics. 3rd ed. 2009: SAGE Publications.

[75] de Vaus, D., Surveys in Social Research. 2002, St.Leonards,NSW: Allen \& Unwin.

[76] M. Alnatheer, Understanding and measuring information security culture in developing countries: case of Saudi Arabia, in Faculty of Science and Technology. 2012, Queensland University of Technology: Brisbane, Queensland, Australia.

[77] M. Alshehri, Using the UTAUT Model to Determine Factors Affecting Acceptance and Use of E-government Services in the Kingdom of Saudi Arabia, in School of Information and Communication Technology. 2012, Griffith University: Brisbane, Australia.

[78] B.G. Tabachnick, and L.S. Fidell, Using Multivariate Statistics. 5th ed. Boston: Pearson, 2007.

[79] J.F. Hair, et al., Multivariate Data Analysis. 6th ed. Upper Sadle River: Pearson, 2006.

[80] J. Pallant, SPSS Survival Manual: A Step by Step Guide to Data Analysis Using SPSS. 2nd ed. Crows Nest, NSW: Allen \& Unwin, 2005.

[81] E. Drost, "Validity and reliability in social science research," Education Research and Perspectives, vol. 38, no. 1, pp. 105, 2011.

[82] R.B. Kline, Principles and Practice of Structural Equation Modeling. 2nd ed. New York: Guildwood, 2005.

[83] P.R. Hinton, et al.,SPSS Explained. East Sussex, England: Routledge, 2004.

[84] J.F. Hair, et al., Multivariate data analysis: a global perspective. 7th ed. New Jersey: Pearson, 2010.

[85] R.H. Hoyle, Structural Equation Modeling: Concepts, Issues, and Applications. Thousand Oaks: SAGE Publications, 1995.

[86] B.M. Byrne, Structural Equation Modeling with AMOS: Basic Concepts, Applications, and Programming. Mahwah, NJ: Lawrence Erlbaum Associates, 2001.

[87] D. Gefen, D. Straub, and M. Boudreau, "Structural equation modeling and regression: Guidelines for research practice," Communications of the association for information systems, vol. 4, no. 7, pp. 1-77, 2000.

[88] B.M. Byrne, Structural Equation Modeling With AMOS: Basic Concepts, Applications, and Programming. 2nd ed. New York: Taylor \& Francis Group, 2010.
[89] D. Harrington, Confirmatory Factor Analysis. Oxford, New York: Oxford University Press, USA, 2009.

[90] A. Bhattacherjee, and G. Premkumar, "Understanding changes in belief and attitude toward information technology usage: a theoretical model and longitudinal test," MIS quarterly, vol. 28, no. 2, pp. 229-254, 2004.

[91] F. Baker, Item response theory: parameter estimation techniques. Vol. 176. 2004, New York: Marcel Dekker.

[92] M. Weitzner, et al., "Developing a care giver quality-of-life instrument. Preliminary steps," Cancer practice, vol. 5, no. 1, pp. 25-31, 1996.

[93] W. Chin, and P. Todd, "On the use, usefulness, and ease of use of structural equation modeling in MIS research: a note of caution," MIS quarterly, vol. 19, no. 2, pp. 237-246, 1995.

[94] T.A. Brown, Confirmatory Factor Analysis for Applied Research. New York: Guilford Press, 2006.

[95] D.Hooper, J. Coughlan, and M. Mullen, "Structural equation modelling: Guidelines for determining model fit," The Electronic Journal of Business Research Methods, vol. 6, no. 1, pp. 53-60, 2008.

[96] P. Barrett, "Structural equation modelling: Adjudging model fit," Personality and Individual differences, vol. 42, no. 5, pp. 815-824, 2007.

[97] Dawes, J., M. Faulkner, and B. Sharp, "Business orientation scales: development and psychometric assessment," paper presented at the 27th EMAC Conference. Stochholm, Sweden, 1998.

[98] P. Greenspoon, and D. Saklofske, "Confirmatory factor analysis of the multidimensional students' life satisfaction scale," Personality and Individual Differences, vol. 25, no. 5, pp. 965-971, 1998.

[99] M. Luthfihadi, and W. Dhewanto, "Technology Acceptance of Ecommerce in Indonesia," International Journal of Engineering Innovation and Management, vol. 3, pp. 9-18, 2013.

[100]E. Karahanna, and D. Straub, "The psychological origins of perceived usefulness and ease-of-use," Information \& Management, vol. 35, no. 4, pp. 237-250, 1999.

[101]T. Alhussain, and S. Drew, "Towards Secure M-Government Applications: A survey study in the Kingdom of Saudi Arabia," paper presented at the 2010 International Conference on Intelligent Network and Computing (ICINC 2010), Kuala Lumpur, Malaysia IEEE, 2010.

[102]L. Carter, L. and V. Weerakkody, "E-government adoption: A cultural comparison, Information Systems Frontiers," vol. 10, no. 4, pp. 473-482, 2008.

[103]K. Faqih, "An empirical analysis of factors predicting the behavioral intention to adopt Internet shopping technology among non-shoppers in a developing country context: Does gender matter?" Journal of Retailing and Consumer Services, vol. 30, pp. 140-164, 2016.

[104]V. Ratten, "Indian and US consumer purchase intentions of cloud computing services," Journal of Indian Business Research, vol. 6, no. 2, pp. 170-188, 2014.

[105] V. Ratten, "International consumer attitudes toward cloud computing: A social cognitive theory and technology acceptance model perspective," Thunderbird International Business Review, vol. 57, no. 3, pp. 217-228, 2015.

[106]R. Safeena, N. Hundewale, and A. Kamani, "Customer's Adoption of Mobile-Commerce A Study on Emerging Economy," International Journal of e-Education, e-Business, e-Management and e-Learning, vol. 1 , no. 3, pp. 228-233, 2011.

[107]T. Al-Tourki, et al., "E-government in Saudi Arabia: Barriers, Challenges and its Role of Development," e-government, vol. 48, no. 5, 2012. 